\title{
Najlepszy przyjaciel człowieka. Pies w roli terapeuty
}

\section{STRESZCZENIE}

W artykule przedstawiono rozwój dogoterapii jako formy rehabilitacji wykorzystującej szczególną relację dwóch gatunków: człowieka i psa. Rys historyczny posłużył zobrazowaniu możliwości wykorzystania dogoterapii w adaptacji oraz readaptacji społecznej osób niepełnosprawnych fizycznie i intelektualnie oraz w leczeniu zaburzeń emocjonalnych.

SŁOWA KLUCZOWE: dogoterapia, rehabilitacja, readaptacja

Rozwój cywilizacji technicznej coraz bardziej oddala człowieka od świata natury, który jest postrzegany jako przeciwieństwo kultury, królestwo dzikich instynktów i prymitywnych popędów. Jednak, jak celnie zauważył Fiodor Dostojewski (1928),

[m]ówi się czasem o „Zwierzęcym” okrucieństwie ludzi, ale uważam, że wyrażając się w ten sposób, krzywdzi się niesprawiedliwie zwierzęta. Zwierzę nigdy nie potrafi być tak okrutne jak człowiek, tak artystycznie, tak po mistrzowsku, tak wyszukanie okrutne (Dostojewski, 1928, s. 200).

W XXI wieku coraz częściej zwracamy się ku zwierzętom, szukając w relacji $\mathrm{z}$ nimi ratunku dla naszego człowieczeństwa i lekarstwa na rany będące skutkiem życia w ludzkim świecie. W poniższym artykule chcę przyjrzeć się więzi, jaka łączy człowieka z psem oraz jej szczególnej formie, jaką jest dogoterapia.

Relacja między człowiekiem i psem jest fenomenem w ujęciu psychologicznym i biologicznym. Pies towarzyszył człowiekowi we wszystkich kulturach, na każdym kontynencie i pod wszystkimi szerokościami geograficznymi. Niezwykłym dokonaniem naszego gatunku stało się udomawianie różnych gatunków roślin i zwierząt. Początek uprawy zbóż związany był z początkiem rewolucji neolitycznej. Jednocześnie $w$ różnych zakątkach naszego globu zachodził proces domestyfikacji (udomowienia) wielu zwierząt. Pierwszy udomowiony przez człowieka gatunek to pies, który jest wyjątkiem pod wieloma względami. Prawdopodobnie został on udomowiony jednorazowo. 
Oznacza to, że pies ma pochodzenie monofiletyczne - od jednej małej populacji wilków. Współżycie człowieka z psem należy zatem uważać za relację mutualistyczną (przynoszącą korzyści obu gatunkom), a proces domestyfikacji psa traktować jako koewolucję obu gatunków (Sipowicz, Najbert i Pietras, 2016, s. 11).

Pies początkowo towarzyszył ludzkiemu stadu, a potem zaczął w nim pełnić różne funkcje. Przygoda ta rozpoczęła się 14 tysięcy lat temu (zob. Przybylińska, 2018, s. 11). W pierwszym okresie pies prawdopodobnie należał do zbiorowości wilka obcującego z człowiekiem. Żywił się resztkami wyrzucanymi przez ludzi wokół obozowisk. Do odpadków dostęp miały jednak tylko te osobniki, które nie przejawiały strachu wobec ludzi. Wilki, które potrafiły przezwyciężyć strach, żywiąc się pozostałościami po posiłkach człowieka, zaczęły żyć blisko osad. Młode osobniki dziedziczyły brak lęku przed ludźmi, a regularność pożywienia pozwalała im wydać na świat zdrowe i liczne potomstwo. $Z$ czasem przodek psa zaczął postrzegać ludzkie stado jako część własnego i ostrzegać je przed zagrożeniem. Wilki miały też inną zaletę, a mianowicie wewnątrz obozowiska odstraszały osobniki z zewnątrz, gdyż postrzegały cały obóz jako swoje terytorium. Te osobniki, które się podporządkowały oraz umiały nawiązać komunikację z człowiekiem, zapoczątkowały populację prapsa domowego. Zaczął on pomagać człowiekowi w polowaniu, wykorzystując własny instynkt. Dostatek pożywienia miał zapewniony w zamian za podporządkowanie się obcemu gatunkowi. Nadzwyczajny węch psa był pomocny człowiekowi w różnych dziedzinach życia - w tropieniu zwierzyny, wyczuwaniu zagrożeń. Pies nauczony życia z ludźmi przetrwał, gdyż z łatwością podjął zadania inne niż polowanie. Strzegł stad zwierząt hodowlanych, pilnował obejścia oraz stał się kompanem człowieka.

Wilk jest gatunkiem stadnym, podobnie jak człowiek. Zwierzęta te żyją $\mathrm{w}$ określonej hierarchii, $\mathrm{w}$ rodzinnych grupach $\mathrm{z}$ dominującym samcem i samicą. Ustaleniu hierarchii $\mathrm{w}$ stadzie służy szereg komunikatów pozawerbalnych. W ludzkich społeczeństwach istnieje podobna hierarchia. Pies, wchodząc w ludzką rodzinę, w procesie udomowienia zajął w hierarchii końcowe miejsce.

Psy mają o wiele bardziej wyczulone zmysły niż człowiek. Ich styl życia i sposób komunikacji powoduje, że muszą polegać na zmysłach w takim stopniu, w jakim człowiek sobie tego nawet często nie może wyobrazić (Przybylińska, 2018, s. 22).

Pies pozawerbalne komunikaty człowieka rozumie doskonale. Człowiek zazwyczaj również potrafi odczytać sygnały pozawerbalne oraz emocje swojego pupila. Komunikaty werbalne pies traktuje jako dźwiękowe komendy, czyli wyłącznie jako pozawerbalne. Pies doskonale rozumie sygnały zapa- 
chowe oraz intonację głosu człowieka. Potrafi również czytać z jego wyrazu twarzy, odróżnić go od psa i zachowywać się inaczej w stosunku do niego. Psy, zwłaszcza pozostające w bliskiej relacji z konkretną osobą, przejawiają wysoką zdolność do empatii.

Szczególna relacja łącząca przedstawicieli obu gatunków oraz zdolności emocjonalne psa stały się podstawą koncepcji korzystania z pomocy psa jako terapeuty. W swoim homocentryzmie widzimy go jako użyteczne narzędzie, lecz przepaść między człowiekiem a zwierzęciem nie zawsze była tak głęboka. W czasach pierwszej religii, jaką był szamanizm, zwierzęta były postrzegane jako przejaw sił przyrody. Dawne ludy przypisywały postać zwierzęcą demonom lub bóstwom. Wierzono także, że dusze zmarłych mogą wniknąć w zwierzę. Dawni łowcy odczuwali mistyczną więź z innymi istotami żyjącymi. Krew stworzeń równała się krwi ludzkiej. W starożytnym Egipcie zwierzęta pełniły funkcje łączników między ludźmi a bogami. Zbliżały one Egipcjan do sfery duchowej. Z głowami zwierząt przedstawiano większość egipskich bóstw. Anubis, strażnik, a pierwotnie władca świata umarłych jest przedstawiany z głową szakala lub pod postacią czarnego psa. Towarzyszył i ochraniał człowieka w drodze do podziemnego świata oraz był obecny w czasie ważenia jego serca (duszy) (zob. Sipowicz, Najbert i Pietras, 2016, s. 21). Co ciekawe, identyczny obraz jest obecny w ikonografii greckiej i bułgarskiej, gdzie św. Krzysztof jest przedstawiany jako Cynocefal - człowiek o psiej głowie. Według wierzeń ludowych miał on pomagać pielgrzymom, przenosząc ich przez niebezpieczną rzekę, a pewnego dnia przeniósł samego Chrystusa pod postacią dziecka (Walczak, 2019). W kulturze chrześcijańskiej pies jest symbolem wierności; katolicki zakon dominikanów, mimo że jego nazwa wywodzi się od imienia założyciela, św. Dominika i łacińskiego słowa dominica - dzień Pański (dies dominica), nazywali siebie Domini canes - „psy Pana”. Wielu świętych jest znanych ze swojej sympatii dla zwierząt, jak np. św. Franciszek, zaś jedna z legend o św. Rochu opowiada o tym, jak został on uratowany przez psa. Natomiast islam zakazuje traktowania psa jako towarzysza. Stworzenia te są uważane za istoty „nieczyste”. Największą obrazą jest nazwanie kogoś „psem”. Muzułmanie twierdzą również, że do domostwa, które zamieszkują czworonogi, nie przychodzą anioły i nie dostępuje ono łask. Odmiennie natomiast postrzega się koty, gdyż te zwierzęta były ulubieńcami Mahometa.

W hinduizmie pies jest wahanq - symbolicznym wierzchowcem, ale także duchem opiekuńczym i przewodnikiem, który przyjął postać zwierzęcą (Szyjewski, 2008, s. 119) - jednego z wcieleń boga Śiwy, straszliwego Bhajrawa, który uosabia szaleństwo (Sieradzan, 2005, s. 353). Jednak sama idea reinkarnacji była źródłem życzliwego stosunku do zwierząt, gdyż powszechnie wierzono 
w możliwość powrotu w kolejnym wcieleniu pod postacią zwierzęcia. Wiarę tę przejęli mieszkańcy starożytnej Grecji. Sławni filozofowie - Pitagoras i Empedokles - szerzyli ideę wegetarianizmu, sprzeciwiając się mordowaniu zwierząt. Wyznawcy orfizmu wierzyli, że po śmierci ciała dusza ludzka może wcielić się w nowy byt fizyczny, na przykład w zwierzę. Natomiast Arystoteles twierdził już, że zwierzęta są stworzone po to, aby służyć człowiekowi. Tak jak rośliny służą zwierzętom, tak one powinny służyć ludziom. Twórca stoicyzmu, Zenon z Kition, uznał, że złe wartości pochodzą od przodków zwierzęcych. I właśnie taki pogląd przejęty przez chrześcijaństwo dominował aż do oświecenia. Oświecenie przyniosło zmianę sposobu myślenia o zwierzętach. Wolter, Rousseau oraz Hume domagali się poszanowania praw wszystkich żyjących stworzeń. Jednak aby udowodnić ludziom, że zwierzęta są czującymi, cierpiącymi istotami, posługiwali się wiwisekcją(!). Natomiast Kant uważał, iż zwierzęta pozbawione są samoświadomości i powinno się je traktować przedmiotowo. Obrazuje to także skrajnie ambiwalentny stosunek do zwierząt we współczesnej kulturze. Z jednej strony, bezmyślnie tępione albo hodowane w okropnych warunkach i zabijane w okrutny sposób, są źródłem białka i innych surowców, z drugiej, bywają wynoszone na piedestał, rozpieszczane, w przypadku niektórych domowych pupilów traktowane lepiej niż ludzie. W obronie niektórych ginących gatunków ludzie potrafią ryzykować życie.

Wiadomo, że przebywanie $\mathrm{w}$ obecności zwierząt daje ludziom wiele radości. Obcowanie z nimi wpływa na naszą sferę emocji. Bardzo często podkreśla się, aby troszczyć się o zwierzęta od najmłodszych lat, bowiem uczy to odpowiedzialności oraz troski o inną istotę. Zwierzęta dają nam również poczucie bezpieczeństwa i stałości. Na przykładzie psów możemy zauważyć, jak doskonale się one $\mathrm{z}$ nami komunikują. Potrafią bronić właściciela oraz chronić przed tym, co postrzegają jako zagrożenie. Tworzą więź podobnie, jak w relacjach międzyludzkich. Obecność psa ogrzewa człowieka w sensie dosłownym (temperatura ciała tych zwierząt jest wyższa niż ludzka) i emocjonalnym - odczuwamy bezpieczeństwo i przyjemność wynikającą z życzliwej obecności. Przytulanie się do psa lub gładzenie go obniża ciśnienie krwi, zarówno u pupila, jak i u człowieka. Dotyk stymuluje ośrodkowy układ nerwowy, następuje redukcja stresu i niepokoju, podwyższa się poziom hormonów: prolaktyny i oksytocyny (odpowiedzialnych za wytworzenie więzi), pojawia się uczucie radości i przyjemności. Te zmiany hormonalne i neurochemiczne mają wpływ na spadek ciśnienia oraz wzrost poziomu dopaminy i endorfin, zwanych hormonami szczęścia.

Aaron Katcher oraz Alan Beck wyróżnili kilka ról i funkcji zwierząt, z których najważniejsze to: towarzyszenie, okazja do pielęgnacji kogoś i opieki nad 
nim, okazja do zajęcia się czymś, możliwość dotykania i głaskania, bezpieczeństwo, obiekt zainteresowania, sposobność do ćwiczeń fizycznych (za: Kokocińska, Kaleta i Lewczuk, 2018, s. 28). Wszystkie te właściwości zwierzęcych towarzyszy człowieka wpływają terapeutycznie na jego funkcjonowanie $\mathrm{w}$ świecie. Ponadto zwierzęta $\mathrm{z}$ pewnością można nazwać stworzeniami inteligentnymi. Aby przystosować się do danego środowiska, muszą one posiadać umiejętność uczenia się i zapamiętywania.

Tak więc mówiąc o inteligencji, w potocznym znaczeniu adaptacji do zmian w otoczeniu oraz szybkości reakcji na nową sytuację i uczenia się, zaliczamy zwierzęta do istot inteligentnych. Trzeba pamiętać o tym, że im bardziej rozwinięte zwierzęta (pot. zwierzęta wyższe), tym bardziej inteligentne zachowania wykazują. Co ciekawe, różne gatunki przystosowały się do odmiennych warunków środowiskowych, zatem wykształciły zachowania, które są opłacalne i praktyczne w ich naturalnym środowisku, a także wiążą się z anatomią. W związku $\mathrm{z}$ tym pytanie o to, czy dany gatunek jest inteligentniejszy od drugiego, traci sens, to jakby dać rybie do rozwiązania test IQ, a człowieka wrzucić w głębinę przed rekinem i czekać, jak zdadzą oni ten egzamin (Kokocińska, Kaleta i Lewczuk, 2016, s. 31).

\section{Historia dogoterapii}

O początkach dogoterapii można mówić już w IX wieku naszej ery. Odbywała się ona przy klasztorach, gdzie w przytułkach umieszczano upośledzone dzieci, a psy pełniły funkcję towarzyszy zabaw i opiekunów-strażników. Europejczycy postrzegali wówczas upośledzenie oraz chorobę psychiczną jako karę za grzechy i stan wymagający całkowitej izolacji człowieka. W średniowieczu istniała ciekawa praktyka: umieszczano takie osoby na specjalnych barkach, które w Niemczech nazywano „statkami głupców”.

Chorych transportowano tymi barkami do miejsc kultu, aby tam doznali uzdrowienia. Były to takie sanktuaria, jak: Saint-Mathurin w Larchant, Saint-Hildevert w Gournay oraz Gheel. W XIII wieku przekształcono ostatnią z wymienionych miejscowości w ośrodek dla obłąkanych (Sipowicz, Najbert i Pietras, 2016, s. 31).

Była to dość niezwykła placówka, jak na tamte czasy. Nowy pacjent był poddawany dziesięciodniowej kuracji wspartej modlitwą i ziołolecznictwem na obszarze kościoła. Jeżeli stan pacjenta nie ulegał poprawie, był on przekazywany do rodziny, w której zostawał do śmierci. Pacjenci byli bardzo dobrze traktowani przez opiekunów. Odrzuceni przez społeczeństwo - w domach tych doznawali bliskości oraz akceptacji. W placówce Gheel chorzy mieli styczność z psami i innymi zwierzętami hodowlanymi. Powierzano im, między innymi, codzienną opiekę i troskę o zwierzęta. W tych warunkach ich 
funkcjonowanie psychiczne i społeczne znacznie się poprawiało. Przedstawione metody terapeutyczne nie były później rozwijane. Od okresu renesansu szpitale zakładało państwo, a nie kościół. „Domy wariatów” przypominały okrutne, przeludnione więzienia.

Przełom nastąpił w wieku XVIII, kiedy osoby psychicznie chore zaczęto postrzegać nieco inaczej. O prawa chorych psychicznie upomniała się protestancka wspólnota wyznaniowa (kwakrzy). Wierzyli oni, że człowiek posiada w sobie „światło wewnętrzne”, które żyje w nim do końca i jest cząstką Boga. Kwakrzy i unitarianie twierdzili, że choroba psychiczna jest następstwem choroby umysłu, a nie - jak twierdzili katolicy - opętania przez szatana.

W roku 1793 kwakierski kupiec, William Tuke, założył na farmie w York Retreat placówkę dla kwakrów z chorobami nerwowymi i psychicznymi. W roku 1796 zaczął on również przyjmować pacjentów innych wyznań. Oprócz leczenia opartego na zrozumieniu, samokontroli i szacunku oraz zasadzie niestosowania przemocy pacjenci zajmowali się psami, zaczynając od karmienia i wyprowadzania ich, na pielęgnacji kończąc. Za przyzwoleniem władz ośrodki prowadzone przez kwakrów powstały w Londynie, Manchesterze, Liverpoolu i Exeter. Takie szpitale jak York Retreat zakładano również za oceanem. W Stanach Zjednoczonych pierwszym był Zakład w Vermont, założony przez Annę Hunt Marsh, gdzie prowadzono zajęcia na powietrzu w specjalnych ogrodach oraz terapię z psami, gdyż wykazywała ona dużą skuteczność. W gazetach ukazywały się artykuły i felietony na temat dogoterapii opracowanej przez kwakrów. Do tych osiągnięć odwołała się później Florence Nightingale, prekursorka współczesnego pielęgniarstwa, która także zaobserwowała bardzo korzystny wpływ psich towarzyszy na żołnierzy (Sipowicz, Najbert i Pietras, 2016, s. 37). Nightingale była również autorką wydanego $\mathrm{w}$ roku 1860 popularnego podręcznika pielęgniarstwa pod tytułem Notes on Nursing. Poświęciła w nim wiele uwagi zagadnieniu dogoterapii. Możemy dowiedzieć się z niego, że obcowanie z psami niweluje ataki paniki, objawy stresu oraz reguluje rytm serca. Poza tym dogoterapię rekomendowała dla osób z niepełnosprawnością fizyczną. Jako pierwsza opisała zjawisko łączącej więzi człowieka ze zwierzęciem, które siedemdziesiąt lat później zaobserwował Sigmund Freud.

W Niemczech, niedaleko miasta Bielefeld, powstał w 1867 roku szpital o nazwie Bethel (Betlejem) dla epileptyków. Inicjatorem jego utworzenia była Misja Wewnętrzna - luterańska organizacja charytatywna powstała w XIX wieku. Z przybyciem do szpitala Friedricha von Bodelschwingha zaczęto stosować w nim dogoterapię. Bodelschwingh pierwszy raz usłyszał o tej metodzie od duchownych, którzy odwiedzali placówki kwakrów w Wielkiej 
Brytanii. Dogoterapię stosowano w Bethel w leczeniu epileptyków, ale również pacjentów z chorobami neurologicznymi i psychicznymi. Von Bodelschwingh zaczął badać możliwości terapii z udziałem innych gatunków zwierząt, zachwycony rezultatami, jakie przynosiła praca z psami. Jako pierwszy zaobserwował i opisał on dobrodziejstwa hipoterapii. Z czasem to Anglicy zaczęli odwiedzać niemiecki szpital, żeby kształcić się w nowatorskiej metodzie terapii i krzewić ją na ziemiach brytyjskich. Placówkę wizytowała Julie Sutter, która postanowiła otworzyć bliźniaczy szpital w Oxfordshire. W 1880 roku powstał tam ośrodek mogący przyjąć aż tysiąc chorych na epilepsję (Sipowicz, Najbert i Pietras, 2016, s. 37).

$\mathrm{Na}$ początku naukowcy nie podchodzili entuzjastycznie do tego rodzaju terapii, jednak efekty, jakie przynosiła, zmusiły ich do prowadzenia rozległych obserwacji, praktyk i badań nad dogoterapią. W roku 1859 wydano dzieło Karola Darwina O powstawaniu gatunków. Uczeni uświadomili sobie, że ludzie należą do świata zwierząt i podlegają jego prawom. Dzięki poszukiwaniu zależności łączących świat zwierzęcy i ludzki rozwinęły się kompleksowe badania $\mathrm{w}$ takich dyscyplinach, jak biologia, socjologia, historia, filozofia oraz psychologia. Naukowcy pokładali wiarę, że tak obszerne ujęcie tematu pozwoli na korzystniejsze przyjrzenie się relacji ludzie - zwierzęta. Dogoterapia przynosząca wyśmienite efekty, nakłoniła uczonych do poszerzania grup pacjentów kwalifikujących się do leczenia tą metodą.

Kolejny przełomowy moment przyniósł rok 1914 - wybuch I wojny światowej. Podczas tego konfliktu zbrojnego wykorzystywano psy do roznoszenia meldunków i korespondencji. Podaje się, że w latach 1914-1918 w sumie zginęło około siedmiu tysięcy psów wskutek działań wojennych po obu stronach konfliktu. Należy też pokreślić, że była to pierwsza z wojen wykorzystujących na skalę masową nowoczesne uzbrojenie: samoloty, czołgi, karabiny maszynowe, miny i gazy bojowe. Liczba rannych i poległych była ogromna. Wielu żołnierzy na skutek działania gazów bojowych traciło trwale wzrok. Normalne poruszanie się było wykluczone, musieli oni korzystać z pomocy psów przewodników. Weterani, którzy borykali się z zespołem stresu pourazowego (PTSD - posttraumatic stress disorder), doznawali również poważnych problemów w normalnym funkcjonowaniu. Uwagę na ich ciężką sytuację zwróciła Dorothy Harrison Eustis. Była ona Amerykanką mieszkającą na stałe w Szwajcarii. Zajmowała się hodowlą i tresurą psów. W roku 1927 Dorothy Eustis opublikowała artykuł dotyczący możliwości włączenia dogoterapii do procesu rekonwalescencji weteranów. Naświetliła w nim trudną sytuację żołnierzy, którzy borykali się z psychicznymi i emocjonalnymi skutkami udziału w wojnie oraz fizycznym kalectwem. Powołała się na przykład 
działań niemieckiego lekarza Gerharda Stallinga, stosującego dogoterapię w swojej praktyce lekarskiej i jednocześnie szkolącego psy do pomocy żołnierzom, którzy na skutek obrażeń wojennych stracili wzrok. Odbywało się to $\mathrm{w}$ ramach jednego ośrodka. Początkowo szkolono w nim psy do pracy w karetkach, którymi przewożono rannych. Żołnierze byli bardziej chętni do współpracy z medykami oraz mniej zdenerwowani, dzięki obecności psów. W 1917 roku doktor Stalling, dyrektor zakładu, wytrenował z myślą o kombatantach niemieckich sto psów rasy owczarek niemiecki. Dwa lata później, po zakończeniu wojny, prywatnych psich przewodników otrzymało 539 byłych żołnierzy. Dr Stalling uzyskał zgodę niemieckiego rządu, w uznaniu zasług, na stworzenie szkoły w Oldenburgu. Trenował on w niej psy do współpracy z niedowidzącymi i niewidomymi. Do roku 1920 wyszkolono w niej ponad sześćset psów. W terapii zwracano ogromną uwagę, aby charaktery człowieka i zwierzęcia były do siebie podobne. Każdy żołnierz, według koncepcji Stallinga, aby unormować psychikę, przechodził zajęcia oparte na dogoterapii. Dopiero później otrzymywał psa przewodnika. Było to potrzebne, aby jak najbardziej zmniejszyć lub wyeliminować całkowicie wśród byłych żołnierzy agresywne zachowanie wobec psów. Dorothy Harrison Eustis stworzyła identyczną placówkę dla weteranów walczących po obu stronach konfliktu (Szwajcaria była neutralna). Pacjentami Eustis byli Amerykanie, Anglicy, Australijczycy, Holendrzy, Niemcy, Francuzi itd. W roku 1928 roku powstała z jej inicjatywy fundacja „The Seeing Eye”, której celem było trenowanie psów - asystentów, przewodników oraz terapeutycznych - dla osób z problemami emocjonalnymi, ociemniałych oraz wojennych weteranów. Organizacja ta do końca roku 1939 wytrenowała oraz przekazała czternaście tysięcy psich przewodników, dziewięć tysięcy psich terapeutów i tysiąc sześćset przewodników przeznaczonych do pracy z weteranami. „The Seeing Eye” działa do dnia dzisiejszego i nadal bardzo aktywnie promuje dogoterapię. Jedyna zmiana, jaka zaszła w tej fundacji, to zmiana wykorzystywanych w terapii ras psów. Do tresury owczarków niemieckich dołączyły takie rasy, jak: buldogi, golden retrivery, labradory oraz border collies.

Na terenie Stanów Zjednoczonych podobne placówki i ośrodki zaczęły powstawać dopiero po ogromnej fali krytyki prasy i społeczeństwa, zarzucającej władzom, że nie do końca należycie opiekują się weteranami wojennymi. W reakcji na nią powołano w 1919 roku oddziały terapeutyczne dla weteranów w waszyngtońskim szpitalu św. Elżbiety, który zgodził się przyjąć psy terapeutyczne do placówki. Szpital św. Elżbiety był pierwszym w USA ośrodkiem, który wykorzystywał hydroterapię i psychodramę w leczeniu pacjentów psychiatrycznych. Do każdego pacjenta forma i metoda terapii była dobierana 
indywidualnie - było to myślenie wyprzedzające epokę postmodernizmu. Stosowano tam takie metody, jak: dogoterapia, psychodrama, biblioterapia czy hortikuloterapia (ogrodolecznictwo). Są to metody oddziaływania środowiskowego na pacjenta. Opieką objęto $\mathrm{w}$ takim samym stopniu pacjentów niebędących weteranami. Szpital prowadził terapię i zajęcia z udziałem trenerów zwierząt, psychologów i psychiatrów. Głównym celem był powrót żołnierzy do życia w społeczeństwie, lecz terapię tę stosowano także wobec osób cywilnych z rozpoznaną depresją, fobią oraz schizofrenią paranoidalną. Terapeutyczne psy były doprowadzane na zajęcia $\mathrm{z}$ weteranami cztery razy w tygodniu.

Również uwadze Sigmunda Freuda nie uszedł pozytywny wpływ psów na ludzi. Freud to twórca psychoanalizy i wybitny austriacki psychiatra. W obecności swojej suczki Jofi, rasy chow-chow (prezent od księżnej Marii Bonaparte), prowadził sesje terapeutyczne. Któregoś dnia, podczas jednej z prowadzonych przez niego sesji, w gabinecie zabrakło psa. Zauważył on wówczas, że pacjent nie był chętny w pełni się przed nim otworzyć oraz stał się bardziej pobudliwy, niż to się zdarzało dotychczas. Od tego dnia suczka Jofi stale towarzyszyła psychiatrze w sesjach terapeutycznych. Freud zaobserwował, że jest jakaś zależność między psem a pacjentem. Chodziło mu o zachowanie suki. Zanotował on w swoim dzienniku, że chow-chow odległością sygnalizuje poziom napięcia u pacjenta. Jeżeli pacjent był bardzo spięty, Jofi pozostawała w znacznej odległości od chorego. Freud uznawał chorego względnie wolnego od napięcia i lęku, kiedy suczka przebywała nieopodal fotela, na którym siedział chory. W momencie gdy pies był bardzo blisko lub pozwalał się pogłaskać choremu, przypuszczał, że terapia prowadzona jest bez zakłóceń. To, jak reagowała suczka Jofi, było niezawodnym wskaźnikiem nastawienia i nastroju pacjenta wobec terapeuty i terapii. Suka siadała w oddali od osób cierpiących na ogromne lęki; w przypadku pacjentów chorych na depresję było zupełnie odwrotnie. Na krok ich nie odstępowała i pozwalała się głaskać. Jofi sama wybierała stopień bliskości oraz zażyłości z pacjentem, działając instynktownie. Trzeba podkreślić, że Freud nie wpływał na zachowanie swojej pupilki. Lekarz przeznaczał pięćdziesiąt minut na pojedynczą sesję, a suczka, w momencie gdy wizyta zbliżała się ku końcowi, z dokładnością najlepszego zegarka, kładła się przy drzwiach gabinetu. Sam psychiatra po stracie wnuka w 1923 roku zaczął cierpieć na depresję, wtedy też skierował się ku dogoterapii. W tym trudnym dla Freuda czasie wspierała go córka Anna oraz jej pies Wolf rasy owczarek niemiecki. W latach późniejszych, gdy psychiatra chorował na nowotwór jamy ustnej, jego pies Topsy również zachorował na tę samą przypadłość. Psy wiernie towarzyszyły 
mu w ostatnich dniach życia, leżąc obok niego na łóżku. Freud zwrócił uwagę oraz wyraził podziw co do szczególnej zdolności psów - odczuwania bezwarunkowej miłości, a także, mimo różnej przynależności gatunkowej, do istnienia między psem a człowiekiem więzi. Zanotował to w swoich pismach. Naukowcy, po upływie trzydziestu lat, potwierdzili jego wnioski. Definiuje się to zjawisko jako Human Animal Bond (HAB). Dla psychiatry psy były takimi samymi członkami rodziny jak ludzie. Może świadczyć o tym fakt, że gdy w roku 1939, z racji swojego żydowskiego pochodzenia, musiał wraz z rodziną opuścić Austrię, wszystkie psy wyjechały razem z nimi do Wielkiej Brytanii.

Anna Freud, córka twórcy psychoanalizy i kontynuatorka jego myśli, także w swojej pracy korzystała z pomocy psów. Na emigracji leczyła dzieci, które doświadczyły cierpień wojny. Prowadziła zajęcia terapeutyczne oraz dalej rozwijała swoją karierę. Anna otworzyła w roku 1957 placówkę obejmującą żłobek, przedszkole i szkołę o nazwie Hampstead Nursery School. Nauczano w niej dzieci, które przeżyły obóz koncentracyjny. Wymagały one specjalnych warunków edukacyjnych oraz indywidualnej i wytężonej psychoterapii. Dzięki pomocy psów Annie Freud i personelowi jej placówki dużo łatwiej było dotrzeć do psychiki podopiecznych. Dzieci te miały problemy z komunikowaniem się oraz były bardzo nieufne, cierpiały często na koszmary senne, trudności z mówieniem, moczenie się w nocy oraz ogromne lęki. Niechętnie również bawiły się z innymi dziećmi. W tych przypadkach prowadzono zajęcia $\mathrm{z}$ udziałem psów. Dzięki nim dzieci nawiązywały relacje społeczne początkowo ze zwierzęciem, a potem z innymi ludźmi.

W tym miejscu warto wspomnieć, że w czasie wojen psy były także najwierniejszymi towarzyszami broni i ogromna ich liczba oddała swoje życie, wykonując powierzone im przez ludzi zadania lub towarzysząc na polu bitwy. Wiele z nich zostało uhonorowanych wysokimi odznaczeniami państwowymi. Ta historia ma też mroczne karty. W czasie II wojny światowej w Związku Radzieckim szkolono psy do wczołgiwania się pod opancerzony pojazd wrogów. Na psach umieszczano ładunki wybuchowe, które detonowano. Hundminen - „psie miny”, jak nazywali je niemieccy żołnierze, były używane do 1944 roku. Zaznaczano, że pod samym Stalingradem i Kurskiem w ten sposób zniszczono dwadzieścia pięć czołgów wroga. Także przygotowując się do eksploracji przestrzeni kosmicznej, ludzie posłużyli się psami. Łajka, pierwszy psi kosmonauta, zginęła z przegrzania na pokładzie radzieckiego satelity Sputnik 2., po niej były kolejne ofiary, dzięki którym można było przygotować odpowiednie warunki do lotów w kosmos dla ludzkich załóg.

Na ogół nie zdajemy sobie sprawy z tego, jak istotną rolę odgrywa w rozwoju naszej cywilizacji relacja człowiek - pies. Kolejne lata potwierdziły użyteczność 
psów w przywracaniu psychicznego i fizycznego dobrostanu osobom cierpiącym na różnego rodzaju dolegliwości. W roku 1969 Boris Levinson - psychiatra dziecięcy i psychoterapeuta - wydał książkę Pet-oriented child psychotherapy, w której opisywał użycie terapii z udziałem zwierząt w leczeniu autyzmu, zespołu Aspergera, zaburzeń uwagi oraz depresji. Jednak książka nie została przyjęta przychylnie przez środowisko medyczne. W latach kolejnych nadal prowadził badania nad dogoterapią, tym razem kilkadziesiąt dzieci zostało podzielonych na grupy. Były to dzieci z zaburzeniami psychicznymi. Każda $\mathrm{z}$ tych grup miała ćwiczenia $\mathrm{z}$ czworonogami innych ras: labradorami i owczarkami niemieckimi; pojawiały się również szczeniaki. Lekarz zaobserwował, że dzieci pracujące ze szczeniakami osiągają najlepsze wyniki. Zwiększyła się u nich reakcja na bodźce zewnętrzne i percepcja, przy czym zmniejszyły się objawy depresji. Levinson do końca życia był propagatorem i entuzjastą prowadzenia terapii z udziałem zwierząt. Uważany jest za twórcę definicji i filozofii pomagania o nazwie pet therapy. W oparciu o to powstały współczesne metody dogoterapeutyczne, które uznają psa za łącznika i pośrednika między pacjentem a terapeutą. Jego osiągnięcia zostały wykorzystane w terapii PTSD u weteranów z Wietnamu. Niestety, terapia ta okazała się skuteczna w 25\% przypadków. Ogromna rzesza uczestników tej wojny uzależniła się od substancji psychoaktywnych, weszła na drogę przestępczą, a więcej niż 130 tysięcy żołnierzy popełniło samobójstwo. Rany zadane przez wojnę w tych wszystkich przypadkach okazały się niemożliwe do uleczenia.

Do twórczości doktora Levinsona w latach 70. XX wieku odnieśli się psychiatrzy pracujący na Uniwersytecie Stanowym Ohio: Elizabeth O'Leary Corson i jej mąż Samuel Abraham Corson. Postanowili oni zrealizować badanie, które miało na celu „ocenę interakcji między genetycznymi i psychosocjalnymi czynnikami w reakcji na stres a siłą więzi społecznych" (Corson i O'Leary Corson, 1975, s. 284). W eksperymencie tym brało udział 20 psów różnych ras. Do dogoterapii zostało wybranych pięćdziesięciu chorych, wobec których tradycyjne leczenie (farmakoterapia, elektrowstrząsy) nie przynosiło rezultatów. Eksperyment był podzielony na klika stadiów. W pierwszej kolejności pacjenci zaznajamiali się z psami, odwiedzając je na ich oddziale. Później role się odwróciły - to psy były przyprowadzane na oddział chorych. Jeżeli pacjent nie poruszał się samodzielnie, psy były doprowadzane do jego łóżka. Kuracjusze obcowali z wieloma psami, aby wybrać zwierzę pasujące do nich najbardziej, w odniesieniu do rodzaju schorzenia i temperamentu. Było to wszystko nagrywane na kasety VHS. Zabieg ten pomagał również w wiernym rejestrowaniu postępów. Pacjenci zostali rozdzieleni na cztery grupy. Jedna $\mathrm{z}$ nich pełniła opiekę nad zwierzętami na oddziale. Kolejna 
wychodziła na przechadzki wokół budynku. Następna grupa mogła wychodzić do przyszpitalnego parku na spacery z psami. Ostatnia z nich miała powierzone zadanie biegania $\mathrm{z}$ nimi po parku. Najlepsze wyniki osiągali pacjenci z dwóch ostatnich grup. Po przejściu dogoterapii aż czterdziestu siedmiu chorych spełniało kryteria pozwalające na wypis z placówki.

Jak widać, dzieje dogoterapii są zawiłe. Ta forma wsparcia występuje pod różnymi nazwami i jest znana już od IX wieku naszej ery. Wielokrotnie zapominano o niej, by później móc „odkryć” ją na nowo. Przynosi ona zaskakujące i trwałe rezultaty, mogą w niej uczestniczyć pacjenci w każdym wieku, z różnego rodzaju dolegliwościami, znakomite efekty przynosi $\mathrm{w}$ pracy $\mathrm{z}$ więźniami, wspomagając proces ich resocjalizacji. $\mathrm{W}$ relacji człowieka $\mathrm{z}$ psem obie strony korzystają z odmiennych form inteligencji towarzysza. W amerykańskich więzieniach do resocjalizacji zaczęto wykorzystywać pozytywny wpływ czworonogów na usposobienie i charakter człowieka. Psy towarzyszące więźniom edukowały ich z zakresu odpowiedzialności i opieki nad istotą zależną. Skazani, szkoląc psy, otwierali im drogę do łatwiejszego znalezienia domu. Projekt „Dogs Behind”, wysoko oceniany na całym świecie, ma swoich licznych zwolenników także w Polsce.

Współcześnie dogoterapia stanowi wyspecjalizowaną gałąź oddziaływań terapeutycznych, w których rolę terapeuty pełni oczywiście człowiek, zaś rola psa jest wspomagająca. Dogoterapia jest metodą rehabilitacji opierającą się na odpowiednio wyszkolonych i przygotowanych psach. Wspomaga ona terapię osób niepełnosprawnych, ruchowo i intelektualnie, osób starszych oraz samotnych, jest też bardzo skuteczna w leczeniu poważnych zaburzeń emocjonalnych. Należy przy tym poczynić rozróżnienie między psem przewodnikiem a psem wspomagającym terapię. Pies przewodnik to asystent, który ma pomagać osobie niepełnosprawnej w codziennych czynnościach. Najczęściej spotykanymi są psi przewodnicy osób niewidomych. Zaś pies terapeutyczny to czworonóg specjalnie wyszkolony do wspierania jakiejś formy terapii; zwierzę stanowi tu narzędzie i łącznik między pacjentem a terapeutą. Tylko prawidłowo wykwalifikowany pies jest w stanie pełnić zaplanowane funkcje terapeutyczne. Dogoterapeuta powinien posiadać wykształcenie związane z terapią: fizjoterapeuty, pedagoga, pedagoga specjalnego, psychiatry, psychologa, oraz odbyć kurs powiązany z szeroko pojmowaną zoologią, na przykład: biologią zwierząt, zootechniką, tresurą lub zoopsychologią. Terapeutę i psa musi łączyć więź opierająca się na wzajemnym zrozumieniu i zaufaniu, gdyż skuteczność terapii jest w dużej mierze owocem ich współpracy.

W Polsce prekursorką dogoterapii jest Maria Czerwińska (prezes Fundacji Przyjaźni Ludzi i Zwierząt „CZE-NE-KA”), która w roku 1987, przy 
okazji realizacji filmu „Widzę” z udziałem niewidomych dzieci, zauważyła, jak pozytywny wpływ na nie ma kontakt z psami, które uczestniczyły w nagraniu. Zaowocowało to częstymi wizytami w zakładzie dla niewidomych w Laskach oraz ośrodkach dla niepełnosprawnych, i stało się impulsem do podjęcia działań formalnoprawnych. Polski Związek Dogoterapii (PZD) powstał w roku 2004, ale dopiero w 2010 pojawił się w Polsce zawód - kynoterapeuta (dogoterapeuta). Od roku 2003 działa w naszym kraju Fundacja „AMA CANEM” (z łac. „Kochaj psa”), powołana w celu prowadzenia zajęć dogoterapii jako działań wspierających terapię osób niepełnosprawnych. Działalność fundacji opiera się na wolontariacie. Większość z ponad 50. odpowiednio przygotowanych wolontariuszy to jednocześnie przewodnicy psów. Są wśród nich terapeuci, lekarze, studenci, uczniowie szkół ponadpodstawowych. Aktualnie w fundacji pracuje 40 wyszkolonych psich terapeutów. Są wśród nich psy rasy: golden retriever, flat coated retriever, labrador retriever, berneński pies pasterski, nowofunland, seter szkocki gordon, seter irlandzki oraz owczarek australijski. Psy zaczynające pracę w fundacji przechodzą najpierw kwalifikacyjne testy psychologiczne, a po ich pozytywnym zaliczeniu są przygotowywane przez trenerów i opiekunów do egzaminów końcowych i pracy w ośrodkach. Przez cały czas uczestniczą w szkoleniach doskonalących i są poddawane okresowym badaniom lekarskim. „AMA CANEM” działa $\mathrm{w}$ wielu placówkach na terenie kraju. W swoich ośrodkach prowadzi dogoterapię dla osób z różnymi rodzajami schorzeń (autyzm, mutyzm, zespół Downa, MPD, ADHD, upośledzenia umysłowe, zaburzenia słuchu i mowy oraz wiele innych). Według danych, znajdujących się na stronie fundacji, psy terapeuci pracują $\mathrm{w}$ 21. ośrodkach, pomagając ponad 9oo. niepełnosprawnym osobom, głównie dzieciom.

Aby zostać dogoterapeutą, pracującym z dziećmi, należy skończyć dziesięciomiesięczny kurs kształcący pedagogów na terapeutów wykorzystujących w swych działaniach psy, a następnie pracować pod okiem superwizora. Szkolenie kończy się egzaminem i uzyskaniem certyfikatu.

Dogoterapia jest wykorzystywana w Polsce od niedawna, lecz dynamicznie rozwija się i staje się coraz bardziej popularna. Głównym elementem metody jest zabawa oraz system ćwiczeń z czworonogami, które asystują $\mathrm{w}$ rehabilitacji umysłowej oraz ruchowej dorosłych i dzieci. Psy mają fenomenalne zdolności wyczuwania zmiany pracy i rytmu serca oraz zapachu skóry. Potrafią również rozpoznać tkankę zdrową i chorą. Tak wyćwiczone psy są w stanie ostrzegać ludzi przed nadejściem ataku padaczki, niedocukrzeniem, wyczuwają także obecność markerów choroby nowotworowej. Wciąż nie znamy skali możliwości, jakie otwiera przed nami perspektywa wyko- 
rzystania psów w diagnostyce, rehabilitacji i terapii. Z powodu tego, że pies jest stworzeniem, które nie ocenia, nie wyznacza jakichkolwiek reguł oraz kocha bezwarunkowo, tworzy niezwykłą więź z człowiekiem. Można i trzeba patrzeć na te stworzenia jako na przydatne ludziom narzędzia, ale zdecydowanie warto docenić ich wierną obecność w naszym codziennym życiu. Może gdybyśmy uczyli dzieci patrzeć na nasze życie na Ziemi jako koewolucję gatunków, nie potrzebowalibyśmy terapii. Doświadczenia dogoterapii wskazują na terapeutyczny charakter relacji człowieka ze światem przyrody. Uważam, że w przestrzeni pedagogiki warto zwrócić uwagę na możliwości, jakie daje szeroko rozumiana edukacja ekologiczna, i poszukać form oddziaływań wychowawczych ukierunkowanych na budowanie pozytywnej, opartej na zrozumieniu relacji z naturą i światem zwierząt.

\section{BIBLIOGRAFIA}

Corson, S.A., O'Leary Corson, E. (1975). Pet facilitated psychotherapy in a hospital setting. Current Psychiatric Therapies, 15, 277-286. Pobrane z: https://www.researchgate.net/publication/21919085_Pet_facilitated_psychotherapy_in_a_hospital_setting, [data dostępu: 06.01.2019].

Dostojewski, F. (1928). Bracia Karamazow. Przeł. A. Wat. Pobrane z: http://bibliogteka.kijowski.pl/dostojewski\%2ofiodor/bracia\%2okaramazow.pdf, [data dostępu: 12.01.2019].

Walczak, D. (2019). Święty psiogłowiec - nietypowe wschodnie przedstawienie św. Krzysztofa. Pobrano z: https://histmag.org/Swiety-psioglowiec-nietypowe-wschodnie-przedstawienie-sw.-Krzysztofa, [data dostępu: 13.01.2019].

Kokocińska, A.M., Kaleta, T., Lewczuk, D. (2016). Zooterapia z elementami etologii. Kraków: Oficyna Wydawnicza Impuls.

Levinson, B.M., Mallon, G.P. (1997). Pet-Oriented Child Psychotherapy. Wyd. 2. Springfield: CS Thomas.

Przybylińska, Z. (2018). Pies. Cała prawda. Warszawa: Agencja Wydawnicza Egros.

Sieradzan, J. (2005). Szaleństwo w religiach świata. Kraków: Wydawnictwo Wanda.

Sipowicz, K., Najbert, E., Pietras, T. (2016). Dogoterapia. Warszawa: Wydawnictwo Naukowe PWN S.A.

Szyjewski, A. (2008). Człowiek i zwierzęta - o totemizmie po Levi-Straussie. W: Etiologia religii. Wyd. 2. Kraków: Zakład Wydawniczy Nomos.

\section{SUMMARY}

\section{The man's best friend. Dog as a therapist}

The development of dog therapy, as a rehabilitation form based on special type of relationship connecting two different species: human being and dog, was described. Historical approach was used to present potential of dog therapy in social adaptation and readaptation of persons physically and/or intellectually disabled as well as its potential in treating different kinds of emotional distress.

KEYWORDS: dog therapy, rehabilitation, social readaptation 